\section{BIOLOGICAL SIGNIFICANCE OF NUCLEIC ACID}

\section{Nucleic Acid}

(Society for Experimental Biology Symposia No. 1 : Published for the Company of Biologists on behalf of the Society for Experimental Biology.) Pp. viit $290+18$ plates. (Cambridge: At the University Press, 1947.) 35s. net.

IN 1914. Walter Jones began the preface to his 1 monograph on nucleic acids with the words, "The nucleic acids constitute what is possibly the best understood field of Physiological Chemistry ..." That was then a tenable point of view; but twenty years later it would have been absurd. There are fashions in everything, including biochemistry, and nucleic acids went largely out of fashion or were swamped by the growth of our knowledge of proteins, oxidation mechanisms and the other processes that characterized the development of biochemistry in the 1930's. The boom-slump-boom cycle is, however, not confined to economics, and a nucleic acid boom is now upon us. Much new knowledge of the intrinsic properties and biological behaviour of the nucleic acids has been gained during the past few years ; but there seems to have been a disproportionate flood of review articles, conferences and symposia. Stocktaking is valuable, but what is now needed in cytochemistry is more stock rather than more surveying.

The present volume gives the text of nineteen papers delivered at a symposium in Cambridge in 1946. The first articles deal with the chemical and physico-chemical properties of nucleic acids and nucleotides, and in them emphasis is placed on the large body of pure assumption that has in the past done duty for knowledge in the field. The late Prof. J. Masson Gulland and his colleagues survey the structural evidence that can be derived from degradation experiments, and point out that the abandonment of the tetranucleotide structure greatly increases the theoretical possibilities of isomerism among the nucleic acids. Evidence on structure is also given in Lythgoe and Todd's brief but lucid description of their extensive series of nucleotide syntheses. Kalckar describes new techniques for the microanalysis of purines by ultra-violet absorption, and gives some of the metabolic conclusions gained with them.

A thoughtful critique of the validity of many cytochemical methods, by Danielli, makes a good introduction to the more biological part of the symposium. Brachet and Caspersson present much evidence that regions or times of intense protein synthesis are correlated with a high nucleic acid content. Although each individual piece of evidence is not by itself wholly convincing, the accumulated mass is most impressive. Two other articles stand in interesting contrast. With pleasing exuberance, Darlington speaks of "nucleic acid as the molecular midwife of all reproductive particles" but, while re-writing cytology, gives no hint, in this article, of the technique and observations on which his conclusions are based. Stedman proceeds more cautiously and continues his valuable attempt to convince cytologists and geneticists that there is more in the nucleus than protamine or histone and nucleic acid. There is perhaps a danger that a new dogma may be built up if the unfractionated protein that can be extracted from all the nuclei that have been studied is called 'chromosomin'. That other proteins are present is obvious; that these proteins are sufficiently uniform in chemical type to deserve a name is arguable.

The printing and format of the book, which appears to be the first of a new series, are good; but it is a pity that the titles of papers have been put at the head of both left- and right-hand pages. It would have been helpful to have the author's name on one side. It is also a pity that such a high price had to be charged for a work which, although useful, is essentially ephemeral.

N. W. PIRIE

\section{NOAH'S NIGHTMARE}

\section{Built Before the Flood}

The Problem of the Tiahuanaco Ruins. By H. S. Bellamy. Revised and enlarged edition. Pp. 192. (London: Faber and Faber, Ltd., 1947.) 21s. net.

TIAHUANACO is an important site in South American archæology, and although it is not the only one, it has something about it which, like Glastonbury, stimulates the imagination of the uncritical, who tend to exalt it above all others. Here are some facts which must be borne in mind in considering it in relation to the subject as a whole Not only its famous stone ruins but also its pottery belong to a very characteristic and easily recognized style. Their distribution in the Andes is restricted to the neighbourhood of Tiahuanaco itself, but on the coast a closely related style in pottery and textiles, little later than the culmination of the style in the Andes, is widespread. This is later than the well. known Mochica culture of the north coast, now dated with some certainty at c. A.D. 1000. When due allowance has been made for the time taken for Tiahuanaco influence to spread from the Andes to the coast, this shows that some time late in the first millennium is a reasonable estimate for its date. In the central and south parts of the coast, preTiahuanaco cultures, earlier than the Mochica but still datable within the first millennium A.D., have yielded abundance of perfectly preserved textiles and other fragile and perishable materials in shallow graves, owing their very existence to continuous drought since they were buried. In the extreme north of Chile, it has been proved that the relation between land and sea cannot have altered more than about 15 metres at the outside (in the sense of a rise of land) since the arrival of pre-pottery man, long before any sign of Tiahuanaco influence.

The contention of this book is, briefly, that Tiahuanaco was built "certainly not less than a quarter of a million years ago", when a satellite preceding the moon dominated the heavens, and that it was overwhelmed by a great "girdle tide" which this satellite raised in the equatorial regions shortly before its disintegration. These ideas are based on the speculations of an Austrian named Hoerbiger, and it is claimed that the carvings on the monolithic gateway at Tiahuanaco constitute a calendar which fits in with his scheme. That we are not told how the older fragile remains on the coast survived an inundation of some $14,000 \mathrm{ft}$. of water and other catastrophic happenings is a consequence of the failure to consider a site in its context, which is frequent in this sort of writing.

The age ascribed to the ruins makes them contemporary with part of the European palæolithic period, when it is most unlikely that man, even at 